\title{
Administrasi Peserta Didik
}

\author{
Alfi Zulfahmi \\ Universitas Negeri Padang \\ Fakultas Ilmu Pendidikan \\ Indonesia \\ E-mail : Alfizulfahmi10@gmail.com
}

\begin{abstract}
Abstrak
Improving human resources in terms of quality can be achieved one of them through education. In the world of education life of students begins when entering school. And to maximeze service for student themselves, there is a system that regulates and covers all the scope needed by student to maximize their potential, which is called the administration of students. This article contains studiens from various sources of literature studies, both from books, journal and from order sources related to educational administration. Administration of students is an activity of recording students from the admission process until students graduate from school or out of school transfer or order causes. In administration of students there is a process carried out by the administrator, namely the activity of beginning of the school year, during the school year, and the end of school year. Instrumen in student administration are master books, book clusters, student condition lists, student attendance books and student file storage files.
\end{abstract}

Keywords-(administration, student, school, education)

\section{PENDAHULUAN}

Administrasi pendidikan merupakan proses atau tahapan atau langkah yang dialakukan oleh suatu organisasi dalam sekelompok orang dengan maksud mencapai tujuan dari organisasi itu sendiri. Dengan demikian dapat dikatakan bahwa administrasi adalah suatu sistem yang saling berkaitan dan mempunyai keterkaitan dan terpaut dengan organisasi. Dalam kata lain dapat diartikan bahwa Administrasi merupakan upaya untuk mencapai tujuan secara efektif dan efisien dengan memanfaatkan orang-orang dalam suatu pola kerja yang sama.

Sedangkan Pendidikan menurut UUSPN 1989 adalah usaha sadar untuk menyiapkan peserta didik melalui kegiatan bimbingan pengajaran dan latihan bagi peranannya di masa yang akan datang.(Suranta, 2017).

Menurut Suryosubroto (2004;25) adapun bidang -bidang yang dikaji dalam administrasi pendidikan diantaranya, administrasi kesiswaan, administrasi kepegawaian, administrasi perlengkapan dan administrasi keuangan. Sebagai anggota masyarakat sekolah siswa mempunyai hak untuk memperoleh bimbingan dan sebagainya. 
Komponen kesiswaan keberadaannya sangat dibutuhkan dan diperlukan, terlebih bahwa pelaksanaan kegiatan pendidikan di sekolah, siswa atau peserta didik sendiri merupakan subjek sekaligus objek dalam proses mentansfer ilmu pengetahuan dan teknologi serta berbagai keterampilan yang diperlukan. Oleh karena itu keberadaan siswa tidak hanya sekedar memenuhi kebutuhan saja, akan tetapi harus merupakan bagian dari ke-bermutuan dari lembaga pendidikan(sekolah), yang berarti dibutuhkan manajemen kesiswaan yang bermutu dan berkualitas bagi lembaga pendidikan (sekolah) itu sendiri. Sehingga siswa dapat tumbuh dan berkembang sesuai dengan potensi fisik, kecerdasan intelektual, sosial, emosional, dan kejiwaan peserta didik. Hal ini tentu membutuhkan banyak tenaga dan sumber daya manusia apabila dilakukan dengan personil atau pegawai sekolah saja, namun jika sekolah menggunakan teknologi informasi dan komunikasi yang ada maka segala aktivitas dapat dilakukan dengan efektif dan efisien.(Rizki, 2014)

Tujuan administrasi kesiswaan adalah untuk mengatur semua kegiaatan-kegiatan peserta didik dari mulai masuk sampai lulus sekolah. Pengaturan kegiatan peserta didik tersebut diarahkan pada peningkatan mutu kegiatan belajar mengajar baik intra maupun ekstrakurikuler, sehingga memberikan kontribusi bagi pencapaian visi, misi, dan tujuan sekolah serta tujuan pendidikan secara keseluruhan.(Risnawati, 2014)

\section{METODE PENELITIAN}

Artikel ilmiah hendaknya disusun dengan metode dan langkah-langkah yang sistematis untuk memudahkan dalam melakukan penelitian. Pada artikel ini, peneliti menggunakan metode dengan terlebih dahulu mengumpulkan bahan kajian dan materi dari sumber buku, jurnal, artikel, maupun sumber lainnya yang berkaitan dengan ilmu dari Administrasi Pendidikan, metode penelitian yang berhubungan dengan topik yang diminati dapat membantu memudahkan dalam merumuskan masalah penelitian, yang mana metode ini disebut juga dengan metode SLR (Systematic Literature Review). Setelah bahan kajian dan materi dikumpulkan, kemudian diteliti dan dipelajari, dibaca serta dipahami. Langkah selanjutnya setelah dipelajari dan diteliti, penulis berusaha menyimpulkan pengetahuan yang penulis analisis dari bahan kajian dan materi tersebut. Metode literatur ini bertujuan untuk membantu kita menemukan wawasan, kebenaran dan juga titik terang (jawaban) dari masalah yang akan diselasaikan. Sebagai petunjuk yang lebih mudah, sederhana dan efisien sebaiknya mengunakan buku-buku denga tanggal hak cipta terbaru. Semakin baru sebuah buku ditulis maka semakin besar wawasan dan kebenaran yang diperoleh.

\section{KAJIAN TEORI DAN PEMBAHASAN}

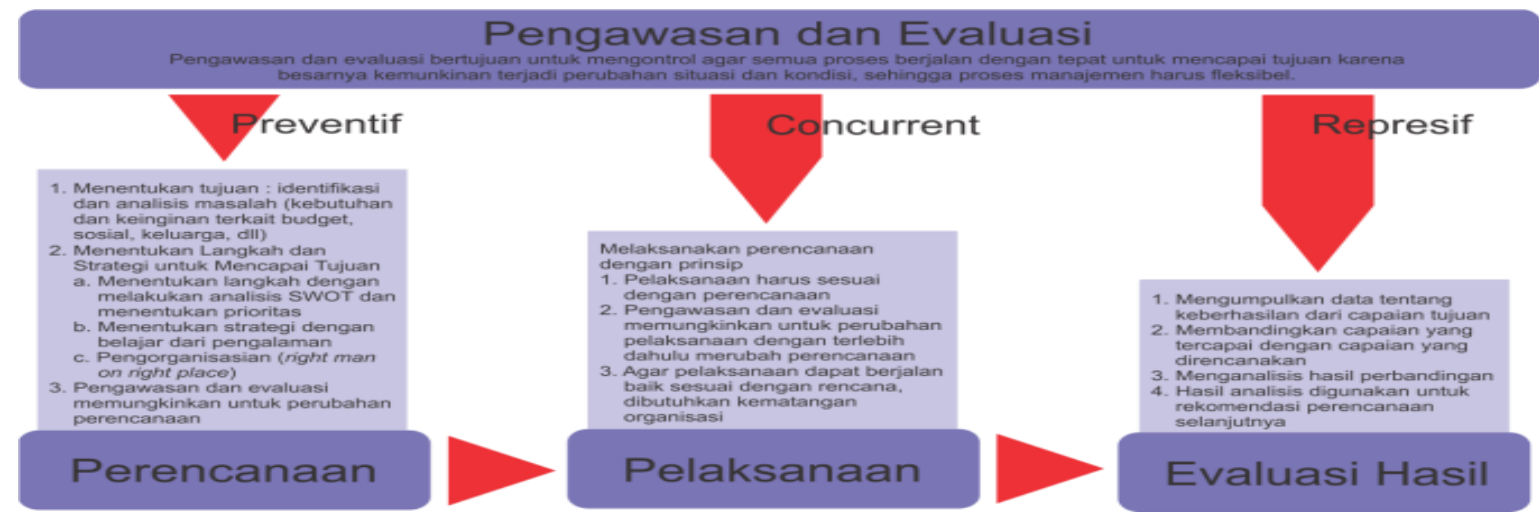


(Afriansyah, 2019).

Berikut cakupan dan ruang lingkup dari administrasi peserta didik.

\section{A. Pengertian Administrasi Peserta Didik}

Siswa merupakan unsur yang sangat penting dalam kegiatan pendidikan dan pengajaran di sekolah. Lembaga pendidikan didirikan edangkan peserta didik / murid / siswa di dalam KBBI berarti orang (anak yang sedang berguru (belajar, bersekolah).

Jadi, dapat disimpulkan secara sederhana bahwa administrasi peserta didik merupakan proses yang dilakukan oleh suatu personil atau kelompok dalam upaya mengelola perserta didik / siswa guna mencapai tujuan dari pendidikan.

Administrasi peserta didik dapat diartikan sebagai proses dari kepengurusan dan pelayanan yang berhubungan dengan peserta didik di suatu sekolah, dimulai dari perencanaan penerimaan murid baru, pembinaan selama masa sekolah hingga murid tersebut menyelesaikan atau menamatkan pendidikannya di jenjang tersebut. Administrasi peserta didik sendiri dilaksanakan dengan menciptakan lingkungan belajar yang kondusif sehingga dapat menciptakan proses belajar mengajar yang efektif. Dalam hal ini tugas dari Kepala Sekolah dan para Guru adalah memberikan layanan terhadap peserta didik. Layanan dalam hal ini dimaksudkan seperti memberikan layanan dengan memperhatikan apa yang dibutuhkan, dirasakan, dan dicita-citakan oleh murid, diberikan sesuai dengan norma/aturan yang ada dan tidak melampaui batas kewenangan dan ketentuan sekolah yang berlaku.

\section{B. Proses Administrasi Peserta Didik}

Dalam proses administrasi peserta didik sendiri terdapat tiga tahapan(proses. Yaitu kegiatan administrasi peserta didik di awal tahun pelajaran, selama tahun pelajaran dan diakhir tahun pelajaran. Perincian dan penjelasan lebih lengkapnya sebagai berikut :

\section{Kegiatan Di Awal Tahun Pelajaran}

Kegiatan di awal tahun pelajaran yang dilaksanakan setiap Sekolah adalah mengadakan penerimaan murid baru. Penerimaan murid ini adalah proses seleksi dan pencatatan murid yang memasuki sekolah tertentu setelah memenuhi persyaratan-persyaratan yang ditentukan oleh sekolah itu.(Afriansyah, 201.9)

Ada beberapa kegiatan yang dilakukan dalam penerimaan murid baru, diantaranya :

\section{a. Penetapan Daya Tampung}

dapat dilakukan dengan rumus :

$$
D Y T=B B \times M B-\mathrm{ATK}
$$

Keterangan :

$$
\begin{gathered}
D Y T=\text { daya tampung } \\
B B=\text { banyaknya bangku } \\
M B=\text { muatan bangku } \\
A T K=\text { anak tinggal kelas }
\end{gathered}
$$




\section{b. Penetapan Syarat-Syarat Murid Baru}

Dengan syarat yang sudah ditetapkan biasanya oleh DEPDIKBUD dan dijadikan pedoman bagi sekolah-sekolah dalam menyeleksi murid / siswa yang akan diterima disekolah tersebut.

\section{c. Pembentukan Panitia/Petugas Penerimaan Murid Baru}

Dimana panitia ini bertugas mengurusi segala bentuk kegiatan yang diperlukan dalam kegiatan rutin penerimaan murid baru disekolah.

\section{Selama Tahun Pelajaran}

Kegiatan/langkah selanjutnya setelah murid diterima di sekolah yaitu membina murid tersebut sehingga berkembang kemampuannya secara maksimal sesuai dengan tujuan sekolah. Pembinaan murid dilakukan agar murid mengenal lingkungan tempat belajar mereka, dan dapat menyesuaikan diri dengan (peraturan yang berlaku) tuntunan sekolah.(Afriansyah, 2019)

Hal-hal yang dapat dilakukan dalam rangka membina peseta didik baru antara lain :

a) Orientasi untuk murid baru

Orientasi siswa baru mencakup kegiatan pada hari-hari pertama sekolah, Masa Orirntasi Siswa (MOS), pendekatan dan teknik-teknik yang digunakan sehingga siswa lebih mengenal lingkungan sekolah yang ditempatinya sebagai tempat dan proses belajar mengajar.

b) Peraturan kehadiran murid

Kehadiran peserta didik di sekolah adalah kehadiran dan keikutsertaan peserta didik secara fisik dan mental terhadap aktivitas sekolah pada jam-jam efektif di sekolah.

c) Promosi dan mutasi murid.

d) Tata tertib sekolah

Salah satu alat untuk melatih kedisiplianan siswa berupa peraturan sekolah yang harus dipatuhi siswa sesuai dengan tuntutan yang diberikan sekolah.

e) Ganjaran dan hukuman

Ganjaran adalah imbalan yang menyenangkan yang diterima murid karena prestasinya dalam berusaha untuk mengerjakan sesuatu. Hukuman adalah imbalan yang tidak menyenangkan yang harus diterima murid akibat tingkah laku mereka dinilai sekolah tidak pada tempatnya. (Risnawati, 2014)

\section{Akhir Tahun Pelajaran}

Adapun kegiatan pada akhir tahun adalah pelaksanaan Ujian Nasional dan Ujian Akhir Semester. Administrasi yang dilakukan berhubungan dengan kegiatan tersebut diantaranya :

a) Pelaksanaan Ujian Nasional

Pelaksanaan Ujian Nasional atau yang lebih dikenal dengan UN ini dilakukan untuk siswa kelas 6 SD, 9 SMP, dan 12 SMA pada akhir tahun pelajaran disemester genap.

b) Kenaikan kelas

Ujian kenaikan kelas dilaksanakan secara serentak terhadap seluruh siswa diakhir tahun ajaran, baik semester ganjil maupun genap. 


\section{Instrumen Administrasi Peserta Didik}

Instrumen administrasi peserta didik (manual \& elektronik).Catatan tentang data siswa di sekolah dibedakan menjadi dua jenis yaitu:

1. Catatan data siswa untuk sekolah, yang meliputi: buku induk, buku kleper, catatan tata tertib sekolah, yaitu kumpulan semua peraturan (bersifat umum dan khusus, ada yanag dari pemerintah dan ada yang produk sekolah itu sendiri).

2. Catatan siswa untuk masing masing kelas yaitu buku kelas yang merupakan cuplikan dari buku induk, buku presensi kelas, buku catatan bimbingan dan konseling buku catatan prestasi murid, yang meliputi buku daftar nilai dan buku lagger,buku raport, dan buku mutasi.

Untuk mempermudah dan memperlancar jalannya administrasi kesiswaan perlu ditunjang oleh berbagai instrumen atau alat kelengkapan yang diperlukan. Adapun instrumen-instrumen yang dimaksud antara lain :

\section{1) Buku induk}

Buku induk ini merupakan buku pokok, karena didalamnya memuat semua informasi yang dianggap lengkap mengenai keadaan siswa.Informasi tersebut dapat meliputi identitas pribadi siswa sampai pada informasi mengenai nilai-nilai hasil belajar yang diperoleh siswa selama belajar di sekolah yang bersangkutan. Buku induk ini sangat penting dimiliki oleh setiap sekolah karena melalui buku induk ini akan dapat diketahui berapa jumlah siswa yang terdaftar, identitas siswa secara lengkap.

\section{2) Buku klaper}

Buku ini merupakan buku pembantu dari buku induk, karena di dalamnya memuat informasi pribadi siswa yang penting-penting. Pengisiannnya dapat diambil dari buku induk tetapi tidak selengkap buku induk itu. Daftar nilai juga tercatat. Kegunaan utama dari buku ini adalah untuk memudahkan mencari data murid, apalagi belum diketahui nomor induknya. Hal ini mudah ditemukan dalam buku klaper karena nama murid disusun menurut abjad.

\section{3) Buku/ keadaan siswa}

Buku ini menggambarkan keadaan jumlah keseluruhan siswa di sekolah. Biasanya gambaran keadaan siswa di suatu sekolah akan terus teridentifikasi dan terpantau untuk setiap bulannya.

\section{4) Daftar hadir siswa}

Daftar hadir siswa ini dibuat untuk mengendalikan keaktifan siswa mengikuti kegiatan di sekolah. Biasa juga disebut dengan daftar kehadiran atau absensi siswa.

\section{5) File penyimpanan berkas siswa}

Berkas-berkas yang sifatnya terlepas-lepas perlu diarsipkan dengan baik oleh sekolah, misalnya foto copy STTB, akte kelahiran, surat keterangan pindah dan sebagainya. Semua berkas itu sebaiknya dikelompokkan.

Selain itu menurut (Suranta, 2017) mengatakan bahwa catatan tentang data siswa di sekopokkan dan disusun menurut kelompok masing-masing, sehingga berkas itu akan mudah ditemukan bila diperlukan. (Afriansyah, 2019)lah dibedakan atas dua yaitu:

1) Catatan data siswa untuk sekolah, meliputi:

a) Buku indukerupakan cuplikan dari buku induk

b) Buku presensi kelas

c) Buku klaper

d) Catatan tata tertib sekolah 
yaitu kumpulan semua peraturan dan tata tertib sekolah ( bersifat umum dan khusus, ada yang dari pemerintah ada yang dari produk (ketentuan) sekolah itu sendiri ).

2) Catatan siswa untuk masing - masing kelas, yaitu :

e) Buku kelas yang $\mathrm{m}$

f) Buku catatan bk

g) Bukucatatan prestasi murid yang meliputi buku daftar nilai dan buku lagger

h) Buku raport, dan

i) Buku mutasi

\section{Peran Guru dalam Administrasi Pendidikan}

1) Sebagai panitia penerimaan murid baru, guru terlibat secara langsung dari proses awal sampai akhir dari penerimaan peserta didik.

2) Berperan dalam memudahkan murid agar dapat beradaptasi cepat dengan lingkungan sekolah. Peran guru ini meuruskan apabila terdapat kekeliruan dalam orientasi yang dapat berakibat kesalahpahaman bagi siswa dalam memahami berbagai peraturan dan tata tertib sekolah, dan juga akan membuat siswa kesulitan untuk lebih cepat beradaptasi dengan lingkungansekolah.

3) Mencatat setiap kehadiran murid secara kontinu dan teliti. Peran guru disini juga tak kalah penting, kehadiran murid disini dicatat setiap pergantian jam pelajaran oleh guru.

4) Menciptakan suasana yang menimbulkan motivasi siswa untuk berprestasi tinggi

5) Menciptakan disiplin sekolah atau kelas yang baik.

Menurut (Afriansyah, 2019) adapun peranan guru dalam pengelolaan murid adalah:

1. Guru dapat dilibatkan secara langsung dalam penerimaan peserta didik baru, dengan menunjuk guru sebagai panitia penerimaan yang dapat melaksanakan tugas-tugas teknis mulai dari pencatatan penerimaan sampai dengan pelaporan pelaksanaan tugas.

2. Peranan dan pengaruh yang besar dalam masa orientasi dipegang oleh guru kelas satu, disamping kepala sekolah. Tugas guru adalah membuat murid dapat lebih cepat beradaptasi dengan lingkungan sekolah.

3. Untuk pengaturan kehadiran murid di kelas, guru pun mempunyai andil yang besar.

4. Guru harus mampu menciptakan suasana yang mendorong timbulnya motivasi murid untuk senantiasa berprestasi tinggi.

Guru juga harus berperanan besar dalam menciptakan disiplin sekolah atau kelas yang baik, karena di sekolah merupakan masa pembentukan disiplin yang sangat menentukan untuk masa selanjutnya. Untuk membuat murid disiplin, guru diharapkan mampu menjadi contoh atau panutan bagi murid-muridnya. 


\section{KESIMPULAN}

Administrasi peserta didik merupakan bagian dari sub administrasi pendidikan, dimana dalam administrasi peserta didik ini mencakup kegiatan pencatatan peserta didik. Dimulai dari proses penerimaan peserta didik di suatu sekolah hingga peserta didik menamatkan pendidikan atau keluar karena alasan pindah dari sekolah tersebut atau bisa juga dikarenakan oleh sebab lainnya.

Kegiatan yang dilakukan oleh administrator peserta didik dalam administrasi peserta didik ada tiga tahap yaitu kegiatan awal tahun pelajaran, selama tahun pelajaran dan akhir tahun ajaran.

Instrumen dalam administrasi peserta didik adalah:

- Buku induk

- Buku klaper

- Buku daftar keadaan siswa

- Buku daftar hadir siswa dan file penyimpanan berkas siswa.

Peran langsung guru dalam administrasi peserta didik :

- Panitia penyeleksi penerimaan peserta didik baru.

- Membantu memudahkan siswa beradaptasi dengan lingkungan sekolah.

- Mencatat dan mengontrol kehadiran siswa, serta melakukan uji kompetensi.

- Menciptakan suasana belajar yang memotivasi.

- Menciptakan disiplin sekolah / kelas yang baik.

Melaksanakan bimbingan karir serta penelusuran lulusan

\section{Daftar Pustaka}

Risnawati. (2014). Administrasi dan Supervisi Pendidikan. (Yogyakarta). Retrieved from http://repository.uin-suska.ac.id/10370/1/Adm dan Supervisi Pendidikan.pdf

Afriansyah, H. (2019). Pengertian dan Proses Administrasi Peserta Didik. (Padang). Retrieved from http://elearning.unp.ac.id/mod/book/view.php?id=80288\&chapterid=1039

Risnawati. (2014). Administrasi dan Supervisi Pendidikan. (Yogyakarta). Retrieved from http://repository.uin-suska.ac.id/10370/1/Adm dan Supervisi Pendidikan.pdf

Rizki, F. A. (2014). Pemanfaatan Teknologi Informasi dan Komunikasi dalam Administrasi Kesiswaan di SMA Negeri 62 Jakarta (2013). (Jakarta).

Suranta, S. (2017). Administrasi Peserta Didik. Retrieved from http://syahsurantaputri.blogspot.com/2017/05/administrasi-peserta-didik.html

Suryosubroto. Manajemen Pendidikan Di Sekolah. Jakarta : PT. Rineka Cipta, 2004 